\title{
A METAMORFOSE DE CLARICE LISPECTOR
}

\author{
Ermelinda Maria Araújo Ferreira*
}

RESUMO: A obra de Clarice Lispector sofre uma guinada a partir dos anos 1960, com o livro de contos Laços de família, escrito durante sua experiência profissional como jornalista responsável pelas colunas femininas publicadas na imprensa carioca nesta década. A menção obsessiva à receita "Como matar baratas" nessas páginas, que vem a dar origem ao conto "A quinta história”, e posteriormente ao romance A paixão segundo $G$. $H$., revela que a autora terá vislumbrado na figura do inseto um potencial capaz de deflagar uma reflexão metalinguística sobre o processo de metamorfose de seu estilo, após a sua prática como cronista.

PALAVRAS-CHAVE: “A quinta história”; Barata; Clarice Lispector; Metafigura.

É que por enquanto a metamorfose de mim em mim mesma não faz. nenhum sentido. É uma metamorfose em que perco tudo o que eu tinha, e o que eu tinha era eu. Não posso fazer nada por você, barata. Não quero fazer nada por você.

É que não se tratava mais de fazer alguma coisa: o olhar neutro da barata me dizia que não se tratava disso, e eu sabia. Só que não estava suportando ficar apenas sentada e sendo, e então queria fazer. Fazer seria transcender, transcender é uma saída. Mas chegara o momento de não se tratar mais disso. Pois a barata não sabia de esperança ou piedade.

Clarice Lispector. A paixão segundo G.H. (p. 63/81)

"A quinta história", texto de Clarice Lispector publicado no livro Felicidade dandeslina': contos (1ª ed.: 1971), figura como uma de suas peças literárias mais enigmáticas. Precedido por diversos relatos sobre "Como matar baratas", publicados em diferentes versões em colunas jornalísticas, inocula o gérmen do famoso inseto cuja "substância vital" a personagem de seu romance $A$ paixão segundo G. H. (1a ed.: 1979) vai engolir numa das cenas mais mesmerizantes da literatura brasileira contemporânea. ${ }^{1}$ Uma cena que reproduz tanto a freudiana concepção do mal-estar na civilização ${ }^{2}$ quanto a temática da náusea sartriana ${ }^{3}$; enquanto estabelece a inconcebível figura de um ser repulsivo, a "barata", como um dos motivos

* Doutora em Letras pela Pontifícia Universidade Católica do Rio de Janeiro (Puc-RJ). Professora Aposentada da Universidade Federal de Pernambuco (UFPE). Realizou estágio pós-doutoral na Universidade Nova de Lisboa.

${ }^{1}$ É inegável a força simbólica que a imagem da barata vai adquirindo ao longo do percurso de amadurecimento profissional de Clarice Lispector. Nádia Batella Gotlib, biógrafa da escritora, atenta por diversas vezes para a importância deste conto em sua obra. Segundo a autora, a ideia surgiu de uma crônica publicada na coluna feminina do jornal Comício, em 8 de agosto de 1952: “O tema de 'matar baratas' foi cultivado (obsessivamente?) ao longo dos jornais antes de chegar à forma do conto, em 'A quinta história', ou do romance, em $A$ paixão segundo G. H.". (GOTLIB, 2009, p. 344)).

2 Para Freud, a cultura (civilização) produz um mal-estar no ser humano ao tolher os seus instintos. Em seu processo evolutivo, a sociedade exige sacrifícios da ordem do desejo, levando à renúncia da satisfação pulsional, prejudicando a expressão da liberdade individual do sujeito.

${ }^{3}$ Cercada por um niilismo exacerbado e por elucubrações de alta profundidade intelectual, $A$ náusea, de Sartre, mostra um protagonista repelido pelas próprias contestações que faz a respeito da falta de sentido, da gratuidade e da ilogicidade da existência. 
fundamentais de sua poética: aquilo que W. J. T. Mitchell definiria como uma "metafigura", ou uma imagem que guarda um valor teórico autoexplicativo.4

A alusão literária a insetos asquerosos não é rara: há "baratas" ilustres nos livros, como a que se notabilizou na novela $A$ metamorfose, de Franz Kafka, cujo enredo fala da conversão de um cidadão modelo num ser desprezível. Caixeiro-viajante, arrimo de família e filho exemplar, Gregor Samsa acompanha sua fantástica e inexplicável transformação num bicho ${ }^{45}$ contra o qual a humanidade desenvolveu um atávico senso de aversão. Num enredo surrealista, a transmutação de seu corpo leva à perda de seus papéis sociais e a uma incômoda dependência de seus parentes, os quais até então sustentava. Destituído de sua identidade e tendo sua humanidade posta em cheque, o personagem vivencia um processo de renascimento íntimo de sua consciência e sensibilidade, até então embotadas pela rotina do trabalho. Aos poucos, o leitor constata, não sem incômodo, a história abusiva e desumanizada do jovem até então, e o abandono a que ele é submetido ao se converter num incapaz. O nojo de seus parentes e amigos parece advir de sua condição dita "inumana", ou seja, de sua súbita inadequação ao sistema, metaforizada na imagem do inseto gigantesco.

Em A paixão segundo G. H., Clarice Lispector faz eco à descoberta de Kafka, ao relatar os percalços de Gregor Samsa, de que o inumano, como diz Lyotard, talvez seja o que de mais legítimo haja em nós ${ }^{6}$ :

Escuta, diante da barata viva, a pior descoberta foi a de que o mundo não é humano, e de que não somos humanos. Não, não te assustes! Certamente o que me havia salvo até aquele momento da vida sentimentizada de que eu vivia, é que o inumano é o melhor nosso, é a coisa, a parte coisa da gente. Só por isso é que,

\footnotetext{
${ }^{4}$ Definidas por W. J. T. Mitchell como Metapictures ("' any picture that is used to reflect on the nature ofpictures"), as metafiguras ilustram uma importante característica da arte moderna, que é a presença de um componente autorreflexivo no interior da própria obra. Utilizadas para pensar as representações plásticas, seu conceito pode ser transposto para uma reflexão teórica sobre o papel de certos signos na literatura, os quais, ao adquirirem um valor simbólico especular, tornam-se tão fortes que já não podem ser concebidos como meras figuras verbais, nem de linguagem nem de pensamento: tornam-se "metafiguras". (MITCHELL. Metapictures, in: Picture Theory (1994)).

5 Blattaria ou Blattodea é uma ordem de insetos cujos representantes são popularmente conhecidos como "baratas". É um grupo cosmopolita, cujas espécies sinantrópicas (menos de 1\%) vivem próximas às habitações humanas devido à disponibilidade de alimento e abrigo. Essas espécies — ratos, pombos, mosquitos e insetos em geral - são consideradas indesejáveis por oferecer ameaça aos estoques de comida, produzir sujeira e transmitir doenças. A principal diferença entre os sinantrópicos e os animais domésticos (cães, gatos, galinhas, cavalos, vacas, porcos, etc.) é que estes são criados em benefício do homem, para a produção de bens de consumo e prestação de serviços, ou como companhia.

6 Diz Lyotard: "Que podemos chamar de humano no homem: a miséria inicial da sua infância ou a sua capacidade de adquirir uma 'segunda' natureza que, graças à língua, o torne apto a partilhar da vida comum, da consciência e da razão adultas? ... podemos tirar partido do título de humanidade por motivos exatamente inversos. Desprovida de palavras, incapaz da paragem certa, hesitante quanto aos objetos do seu interesse, inapta no cálculo dos seus benefícios, insensível à razão comum, a criança é eminentemente humana, pois a sua aflição anuncia e promete os possíveis. O seu atraso inicial sobre a humanidade, que a torna refém da comunidade adulta, é igualmente o que manifesta a esta última a falta de humanidade de que sofre, e o que a chama a se tornar mais humana.” (LYOTARD, 1997, p. 11)
} 
como pessoa falsa, eu não havia até então soçobrado sob a construção sentimentária e utilitária: meus sentimentos humanos eram utilitários, mas eu não tinha soçobrado porque a parte coisa, matéria do Deus, era forte demais e esperava para me reivindicar. (LISPECTOR, 1986, p. 65)

O inseto eleito pela autora como metafigura em sua obra também é mais um entre os vários seres nomeadamente considerados “imundos” pela Bíblia. Este aspecto é igualmente alvo de um discurso filosófico desconstrutor e quase herético no romance clariciano, no qual a personagem G.H. se aproxima do universo abjeto, proclamando o desejo de "queda" que atravessa a escrita de Clarice Lispector:

Eu me sentia imunda como a Bíblia fala dos imundos. Por que foi que a Bíblia se ocupou tanto dos imundos, e fez uma lista dos animais imundos e proibidos?... Eu estava sabendo que o animal imundo da Bíblia é proibido porque o imundo é a raiz - pois há coisas criadas que nunca se enfeitaram, e conservaram-se iguais ao momento em que foram criadas, e somente elas continuaram a ser a raiz ainda toda completa. E porque são a raiz é que não se podia comê-las, o fruto do bem e do mal - comer a matéria viva me expulsaria de um paraíso de adornos, e me levaria para sempre a andar com um cajado pelo deserto. Pior - me levaria a ver que o deserto também é vivo e tem umidade, e a ver que tudo está vivo e é feito do mesmo. Para construir uma alma possível a lei manda que só se fique com o que é disfarçadamente vivo. E a lei manda que, quem comer do imundo, que o coma sem saber. Pois quem comer do imundo sabendo que é imundo - também saberá que o imundo não é imundo. É isso? (Clarice Lispector. A paixão segundo G.H., 1987, p.68)

Se o romance é perpassado por um discurso hipnótico e metafísico que oculta deliberadamente o tema primordial da narrativa, raramente apreendido pelos críticos da $\mathrm{obra}^{7}$; o pequeno conto que o antecede e anuncia, “A quinta história”, também pode parecer a uma leitura desavisada tão enigmático e estranho que beira a incompreensão. O surpreeendente é que, colocado sob uma perspectiva histórica e relacionado à biografia da autora, adquire uma clareza surpreendente e quase luminar sobre o contexto de sua atividade de escrita, podendo ser considerado uma peça exemplarmente metaficcional, que explica e reflete sobre a natureza de sua proposta intelectual e artística.

Para que se entenda o que Clarice terá querido dizer com essa aparentemente despretensiosa narrativa, é preciso lembrar que "A quinta história" surge, efetivamente, na época em que a escritora trabalhava como colunista em suplementos ou em cadernos dos jornais especialmente dedicados ao público feminino. Tarefa desenvolvida nos anos 1950608, iniciada por motivos principalmente financeiros - resultantes da situação em que se encontrou

\footnotetext{
${ }^{7}$ Nesta obra, o diálogo com o conto se estabelece num aspecto ainda mais radicalizado. Constituindo-se uma espécie de sofrido depoimento sobre a culpa feminina ante um aborto voluntário - questão ainda tabu na conservadora sociedade burguesa brasileira das décadas de 1960-70, apesar das lutas feministas que acompanhavam os movimentos libertários da época -, o aspecto da "imundície" atribuída ao inseto torna-se mais importante do que o aspecto de sua "vulgaridade" (de "vulgo": relativo ou pertencente à plebe; popular, banal, comum, corriqueiro, ordinário, usual), mais profícuo para os objetivos da narrativa em "A quinta história", como se verá.
} 
após o divórcio ${ }^{89}$, sem ocupação definida e com dois filhos para criar -, consistia na elaboração de páginas típicas de uma conversa ao pé do ouvido com o estereótipo feminino dominante naquele período, alimentando-o e reforçando-o. A interlocutora desse tipo de literatura era a mulher de classe média e de meia idade, em geral casada, com filhos, dedicada às tarefas domésticas e sem maiores perspectivas na vida além de se embelezar para o marido, monitorar a saúde e a educação das crianças e se entreter com pequenas atividades artesanais e culinárias, e com informações gerais e superficiais sobre diversidades.

O momento político no Brasil naquele período também não convidava à abordagem de assuntos espinhosos nem a manifestações de rebeldia, sobretudo quando a sobrevivência estava em jogo, como parece ter sido o caso da autora. Reforça essa suposição o fato de que Clarice preocupou-se muito em ocultar a sua atividade como colunista, encontrando nas máscaras de dois pseudônimos, Teresa Quadros e Helen Palmer, e na figura pública da atriz famosa Ilka Soares, de quem se assumiu como ghost writer, uma forma de não comprometer a sua imagem como escritora polêmica, revolucionária e definitivamente forte, num cenário dominado por intelectuais do sexo masculino que pouco espaço conferiam às mulheres, mesmo aquelas que se mostravam mais excêntricas, como prova o tipo de atividade jornalística para o qual foi cogitada, mesmo por amigos como Alberto Dines, Rubem Braga e Fernando Sabino.

Uma tarefa que ela aceitou mas não assumiu, e que deverá ter sido, em certos momentos, vivenciada de modo humilhante, sobretudo por uma escritora com um perfil tão afeito à insubordinação, e que atravessava exatamente um momento pessoal conflituoso com o fim da relação conjugal, por sua iniciativa, e o início de uma vida independente, ainda posta sob suspeita no seio da sociedade brasileira preconceituosa e misógina de meados do século XX.

Estar em meio a um processo de divórcio, ganhando a vida como uma colunista free lancer, responsável pela concepção de páginas femininas medíocres nas quais era obrigada a defender ideias opostas aquelas em que acreditava, deve ter parecido à lúcida e erudita Clarice uma amarga ironia do destino. "Um vago rancor me tomara, um senso de ultraje", diria ela em "A quinta história" (LISPECTOR, 1987, p. 154). Uma ironia que, no entanto, terá

\footnotetext{
8 Clarice Lispector inaugura sua atividade como responsável pela coluna feminina "Entre mulheres" do semanário Comício, a convite do amigo Rubem Braga, em 1952, tarefa que exerceu por seis meses com o pseudônimo “Teresa Quadros". Já no Correio da manhã, voltou a exercer esta função de agosto de 1959 a fevereiro de 1961, como responsável pela seção "Feira de utilidades" na página Correio feminino, sob o pseudônimo "Helen Palmer". Já no tablóide Diário da manhã atuou como ghost writer da atriz Ilka Soares, na coluna "Só para mulheres", de abril de 1960 a março de 1961. (Cf. NUNES, 2006, p. 27).

${ }^{9}$ A escritora divorcia-se do diplomata Maury Gurgel Valente, com quem vivia no exterior, e volta para o Rio de Janeiro com os dois filhos em junho de 1959.
} 
exercido o seu papel, contribuindo para que a autora realizasse um "laboratório" inusitado, que pelo sentimento de afronta com que terá sido vivenciado e a reação que possivelmente terá provocado em seu espírito, muito colaborou para o seu verdadeiro encontro com um estilo próprio, pessoal e inconfundível.

O estilo "hermético" e "místico" (e consequentemente inacessível à maior parte do público leitor brasileiro), anunciado e muito criticado nos romances escritos numa fase anterior a essa experiência - Perto do coração selvagem (1943), O lustre (1946), A cidade sitiada (1949) e $A$ maçã no escuro (1961) -, sofre um desvio radical no início dos anos 1960, com a publicação do livro de contos Laços de família. Diversos pesquisadores assinalam esta mudança, embora não a associem à experiência da autora na imprensa, nem ao conflito gerado pela coincidência deste emprego com o momento da separação conjugal, que certamente terá desafiado uma mulher como Clarice a um interessante exercício íntimo de despersonalização, sempre muito útil no processo de geração da escrita.

Sonia Roncador comenta que, no fim dos anos 1950, não havia um só editor interessado em publicar a obra de Clarice, cuja fama se restringia a um pequeno grupo de intelectuais. Somente nos anos 1960 suas publicações ganharam um reconhecimento maior, porém seus textos ainda eram recebidos com desconfiança por leitores e críticos, que os consideravam vagos, ou ainda pior, reacionários:

\begin{abstract}
A excelente reputação da qual sua obra passou a gozar sobretudo no final da década de 1960 tem sido em parte atribuída aos estudos realizados pelo crítico paraense Benedito Nunes. ... Embora seu primeiro romance, Perto do coração selvagem, tenha causado uma impressão favorável na crítica (sem contar a excelente impressão causada por Laços de família), a maioria de suas publicações foi, no entanto, recebida com certa desconfiança. ... Nos anos 1960, seus romances eram considerados um enigma e suas intenções ininteligíveis. Os primeiros intentos de Benedito Nunes de definir a arte e a trajetória artística de Clarice contrastam com o silêncio quase absoluto que, segundo ele próprio, caracterizava a reação dos críticos frente aos romances da autora, considerados 'um culto à vaguidão e ao hermetismo'. (RONCADOR, 2002, p. 92)
\end{abstract}

Os principais índices da produtividade deste conflito no espírito da autora residem na opção pelo conto, um gênero mais curto e acessível, muito mais atraente a uma leitura fugaz do que os longos e pormenorizados monólogos aos quais ela havia se dedicado até então em seus complexos romances. Possivelmente fruto da prática diária com a escrita das colunas, rápidas e diretas, os contos de Clarice apresentam uma migração temática e um estreito diálogo com o texto jornalístico, aspectos já atestados por pesquisadores como Edgar Cézar Nolasco e Aparecida Maria Nunes, os quais, no entanto, não conferem relevo à experiência de Clarice com as páginas femininas na gênese de sua obra "madura".

O título da obra que pode ser considerada o "divisor de águas" de sua produção 
também corrobora a hipótese de uma influência direta de sua atividade jornalística na busca de uma nova abordagem estética na literatura. Laços de família resgata exatamente o universo tratado nas crônicas, o espaço doméstico, habitat natural da mulher, congregando histórias em geral relacionadas aos personagens e ao cotidiano do lar: as donas de casa e seus destinos nas várias etapas da vida, os filhos e seus desafios, o amor e suas descobertas e frustrações.

Mas o que terá talvez sido decisivo para esta mudança reside na opção por uma técnica peculiar, que virá assinalar a sua diferença na literatura brasileira: a epifania. A produção de uma escrita epifânica deliberada, baseada na introdução, no decorrer da história, de um momento de iluminação para assinalar a tomada de consciência, seja da personagem, seja do leitor ou de ambos, sobre um aspecto da realidade ou de suas próprias vidas até então experimentado automaticamente, data da publicação de Laços defamília. É no âmbito da obra que a autora procederá a uma construção ficcional bastante específica, que se diferencia do estilo usado nos romances anteriores não só pela escolha da história curta, mas de uma história que abre à banalidade da existência - com a qual terá convivido estreitamente no corpo da crônica - uma inusitada concessão.

As histórias começam de um modo convencional, e às vezes em torno de um tema completamente pífio, para evoluir rumo ao insight - o clímax dito "epifânico" do enredo - e depois resvalar na escrita automática e filosófica que já lhe era peculiar. Este procedimento terá sido, talvez, a virada mais importante de Clarice no sentido de compor uma obra mais acessível, sem prescindir da natureza da mensagem que desejava veicular. A sua popularidade, hoje, provavelmente deve muito à sua experiência como cronista de colunas femininas, exercício de humildade necessário que lhe impôs a sábia vida que a queria escritora, e escritora lida e conhecida; e aos contos que resultaram desta experiência. Não raro são eles que introduzem o leitor no universo clariciano, e o levam a se aventurar nos romances, tanto os da primeira fase quanto os que se seguiram aos contos e já vieram marcados pela técnica epifânica: A paixão segundo G. H. (1964), Uma aprendizagem ou o livro dos prazeres (1969), Água viva (1973), A hora da estrela (1977) e Um sopro de vida (1978). De fato, se Clarice continuasse na linha estritamente esotérica que exercitou na primeira fase de sua produção, não teria certamente angariado a legião de admiradores que hoje a cerca.

O motivo da "queda" no abjeto e a escolha de uma inusitada metafigura para ilustrar esse processo adquire, no contexto assim considerado, uma importância fundamental. O fato de que esta metafigura, o inseto "imundo", tem por nome vulgar "barata" não escapa à percepção da artista, que parece ver nesta coincidência uma alusão significativa e até irônica ao seu próprio percurso como escritora. Muito jovem, ela se inicia um tanto soberba, com um 
discurso "elitizado", muito além e acima do entendimento geral do horizonte de recepção de seu tempo e lugar. Mas a extrema juventude ainda não lhe permite perceber que o escritor, mesmo aquele que não pretende ceder a pressões externas, não pode prescindir do leitor sem pulverizar a si mesmo. É preciso descer, é preciso vivenciar a queda, é preciso deglutir a substância vital e barata da humanidade comum e espúria, que deplora, mas da qual faz parte, e com a qual precisa e deseja se comunicar.

Como um Cristo. Não por acaso a queda de um Deus no corpo de um homem é um assunto que perpassa toda a sua produção. Mas a experiência efetiva desta queda só terá sido vivida por Clarice, em termos intelectuais, durante a sua prática jornalística até certo ponto "infamante". E vivida como um Cristo, como uma divindade caída em desgraça, cuja experiência, filtrada pela instintiva sabedoria que caracteriza a autora, é aproveitada como um aprendizado evolutivo do qual sai renovada e liberta. "A quinta história" talvez seja, dos contos de Clarice, o que melhor relata a natureza do processo. O que mais claramente revela (em termos claricianos) a sua experiência de encontro consigo mesma, na definição de um estilo pessoal, elevado, mas ao mesmo tempo comunicativo e "barato", e na percepção de uma escrita que consegue ser "simples" sem deixar de traduzir a complexa essência de seu ser.

O próprio conto exemplifica a teoria que lhe fornece o tema. Construído em "ondas", apresenta cinco momentos, identificados por títulos diferentes relativos às cinco histórias cujos esboços a autora vai desenvolver brevemente. Na primeira, "Como matar baratas", o mote é apresentado:

A primeira, "Como matar baratas", começa assim: queixei-me de baratas. Uma senhora ouviu-me a queixa. Deu-me a receita de como matá-las. Que misturasse em partes iguais açúcar, farinha e gesso. A farinha e o açúcar as atrairiam, o gesso esturricaria o de-dentro delas. Assim fiz. Morreram. (LISPECTOR, 1987, p. 154)

O parágrafo refere-se a um trecho publicado mais de uma vez nas colunas femininas sob sua responsabilidade. Todas as referências são, portanto, literais, e atestam a precariedade dos temas com os quais Clarice precisava lidar no seu cotidiano de trabalho. A "vizinha" era um recurso usado pela autora para criar maior empatia com suas leitoras, valendo-se de uma simulação dos bate-papos informais e das conversas e fofocas tidas como habituais entre as mulheres, e comuns especialmente entre vizinhas, num tempo em que o isolamento urbano não era tão marcante como ocorre atualmente nas grandes cidades.

Naquela época era frequente o intercâmbio de receitas e "dicas" relativas às tarefas domésticas, ainda ao encargo das mães de família, e não terceirizadas e profissionalizadas como hoje. Embora pudesse ocorrer à leitora de Clarice comprar um inseticida no mercado, ou mesmo chamar uma empresa dedetizadora, a troca de informações entre amigas e 
comadres pareceria mais confiável, mais econômica e mais interessante. A tarefa do extermínio das pragas caseiras, entre tantas outras, ainda dependia da sabedoria adquirida com a experiência, via tentativa e erro, e a eficácia das receitas era repassada entre as mulheres, numa rede de relações de cumplicidade e solidariedade reproduzida por Clarice no universo de suas colunas. O texto, portanto, é direto e referencial: não há interstícios nem espaço para segundas intenções; não há a mínima possibilidade de "leituras nas entrelinhas", simplesmente porque não há “entrelinhas" neste relato. A sua obviedade é clara: baratas são insetos nojentos conhecidos por todos, e sabidamente indesejáveis em domicílios bem cuidados; a mistura de açúcar, farinha e gesso é exatamente o que parece, e o efeito dessas substâncias deverá corresponder ao que é explicitado: eliminar os bichos imundos.

A segunda história incorpora a primeira e assinala o procedimento de "deglutição" do texto sobre si mesmo, onde o material bruto da história anterior é incorporado num mecanismo antropofágico que o absorve e o transforma, acrescentando um dado novo que ressignifica o enredo sob nova perspectiva. Daí a afirmação: "A outra história é a primeira mesmo e chama-se "O assassinato". O acréscimo produzido com a alteração no título, porém, rasga entre as linhas da primeira história possibilidades inusitadas. A palavra "assassinato" transfere para o signo "baratas" uma qualidade humanizada, inexistente no texto anterior, pois não se usa "assassinar" baratas, mas pessoas. Já não podemos, portanto, perceber as baratas como meros insetos: elas sofrem na segunda história uma metamorfose que as antropomorfiza mesmo à revelia de nossa percepção imediata. A primeira história é, então, resumida: “Começa dizendo que eu me queixara de baratas. Uma senhora ouviu-me. Segue- se a receita. E então entra o assassinato". Além do novo título, a autora acrescenta novas informações, que vão conferindo opacidade à narrativa e convertendo a linguagem transparente da receita num texto literário:

\begin{abstract}
A verdade é que só em abstrato me havia queixado de baratas, que nem minhas eram: pertenciam ao andar térreo e escalavam os canos do edifício até o nosso lar. Só na hora de preparar a mistura é que elas se tornaram minhas também. Em nosso nome, então, comecei a medir e pesar ingredientes numa concentração um pouco mais intensa. Um vago rancor me tomara, um senso de ultraje. ... Como para baratas espertas como eu, espalhei habilmente o pó até que este mais parecia fazer parte da natureza. De minha cama, no silêncio do apartamento, eu as imaginava subindo uma a uma até a área de serviço onde o escuro dormia, só uma toalha alerta no varal. Acordei horas depois em sobressalto de atraso. Já era de madrugada. Atravessei a cozinha. No chão da área lá estavam elas, duras, grandes. Durante a noite eu matara. Em nosso nome, amanhecia. No morro um galo cantou. (LISPECTOR, 1987, p.155)
\end{abstract}

As informações são importantes: de início, as baratas não representavam um problema para a autora, que não tinha sequer consciência de suas existências, vindas de um "andar térreo" - um lugar inferior, portanto - e invadindo o recinto mais desqualificado do 
apartamento, a área de serviço, que não parecia muito frequentada por ela. Se admitirmos que essa história vai construindo um discurso especular ou metalinguístico, torna-se fácil imaginar que Clarice começa a revelar, neste segundo momento do conto, uma tomada de consciência de seu papel como cronista e dos efeitos prováveis de sua atividade sobre o público vulgar ao qual se dirigia no "veneno da noite", quando certamente compunha as suas colunas como quem "avia o elixir da longa morte". Não da "morte breve" - atente-se - a morte orgíaca, la petite mort, que em francês significa “orgasmo": curto período de melancolia, transcendência ou relaxamento do espírito que resulta da experiência de um intenso e vívido prazer, mais frequentemente referido ao prazer sexual. Roland Barthes, porém, dizia que la petite mort era equivalente ao efeito produzido na alma do leitor diante de uma grande obra literária. ${ }^{10}$ De onde se deduz que, ao aviar um "elixir da longa morte", Clarice tinha consciência de sua queda numa atividade indigna - ultrajante, em suas próprias palavras - que trabalhava para o embrutecimento e para a anestesia dos espíritos, e não para a sua exultação.

E era com rancor que ela se debruçava sobre a tarefa, aviando a receita, desta vez "numa concentração mais intensa" - afinal, tratava-se aqui da história segunda, redigida provavelmente num momento posterior ao das crônicas, quiçá o da redação do próprio conto no qual reflete metaforicamente sobre sua atividade jornalística. A analogia das "baratas" com as "mulheres" é confirmada pela frase irônica: "como para baratas espertas como eu", que designa, provavelmente, o cuidado com que a autora disfarça o seu estilo (o "pó”), de modo a parecer "natural" à leitura de seu público faminto, porém pouco exigente e muito conformado. A ansiedade pela manhã, quando veria o resultado do "assassinato" na leitura do jornal que era entregue com o pão e o leite às portas das casas, é relatada com a minúcia de uma criminosa, alguém que se sabe conivente com o envenenamento diário de outras mulheres, ávidas de vida, por uma literatura medíocre e aviltante. Pela manhã, constata o estrago, percebe o efeito desastroso de sua intervenção noturna: "elas", as pobres mulheres, jazem aos montes, grandes e duras, mortas. Seria isso o que Clarice desejaria para si e para as suas leitoras?

Uma nova “onda" engole então a segunda história, incorporando-a à terceira. Cada

10 Em O prazer do texto, Roland Barthes analisa dois tipos de efeitos literários: plaisir ("prazer") e jouissance ("gozo"), palavra francesa que também significa "orgasmo" (la petite mort). A distinção corresponde a uma diferença entre texte lisible ("texto legível”) e texte scriptible ("texto escrevível”). O primeiro produziria o prazer, não desafiando a posição do leitor como sujeito. O segundo produziria a felicidade, ao explodir os códigos literários, promovendo a ruptura do leitor com seu lugar de segurança. O texto "escrevível", ou "de fruição", seria, portanto, "aquele que põe em estado de perda, aquele que desconforta (talvez até um certo enfado), faz vacilar as bases históricas, culturais, psicológicas, do leitor, a consistência de seus gostos, de seus valores e de suas lembranças, faz entrar em crise sua relação com a linguagem.” (BARTHES, 1987, p. 24). A obra de Clarice Lispector, sem dúvida, exercita todos os modos de gozo possíveis, no sentido barthesiano, através da palavra. 
história resume a anterior numa clara alusão ao devoramento, e acrescenta novos dados. As histórias vão-se alongando e ganhando complexidade e densidade. Diz Clarice: "A terceira história que ora se inicia é a das "Estátuas". ${ }^{11}$ Começa dizendo que eu me queixara de baratas. Depois vem a mesma senhora. Vai indo até o ponto em que, de madrugada, acordo e ainda sonolenta atravesso a cozinha". Enquanto a história anterior focalizava o problema da produção e o dilema da autora, a terceira história demora-se divagando sobre o público "barato". Um público que é retratado nesta peça de modo surrealista, quase cinematográfico, com um aprofundamento ainda mais radical do que na história anterior. A definição é surpreendente:

Mais sonolenta que eu está a área na sua perspectiva de ladrilhos. E na escuridão da aurora, um arroxeado que distancia tudo, distingo a meus pés sombras e brancuras: dezenas de estátuas se espalham rígidas. As baratas que haviam endurecido de dentro para fora. Algumas de barriga para cima. Outras no meio de um gesto que não se completaria jamais. $\mathrm{Na}$ boca de umas um pouco da comida branca. Sou a primeira testemunha do alvorecer em Pompéia. Sei como foi esta última noite, sei da orgia no escuro. Em algumas o gesso terá endurecido tão lentamente como num processo vital, e elas, com movimentos cada vez mais penosos, terão sofregamente intensificado as alegrias da noite, tentando fugir de dentro de si mesmas. Até que de pedra se tornam, em espanto de inocência, e com tal, tal olhar de censura magoada. (LISPECTOR, 1987, p.155)

"Sou a primeira testemunha do alvorecer em Pompéia": uma frase que desloca radicalmente a descrição anterior para um espaço mítico e simbólico, metaforizando os corpos já antropomorfizados das baratas "grandes e duras" da história anterior na sedutora e prolífica imagem de estátuas "rígidas e brancas", poeticamente imobilizadas através da eternidade de seus corpos na temporalidade de um gesto.

Há uma certa comicidade no processo pelo qual o retrato das mulheres-leitoras vai sendo construído e reconstruído no imaginário de Clarice, como se a autora se divertisse infinitamente em explorar as possibilidades da recém-nascida metafigura da barata. Agora, ela lhe serve para imaginar um cenário devastado, calcinado e estéril, ao qual tem acesso por um corredor de ladrilhos, "sonolento" ele mesmo e já completamente diferente da referência a um mero corredor, parecendo um tubo distorcido pela alteração perceptiva da narradora, que sugere estar ela mesma sob o efeito de alguma droga ou veneno capaz de produzir alucinações.

Assim como a segunda história parece evocar o conto que ora se desenvolve, a terceira

11 A suposição de que esta história reside na gênese do livro $A$ paixão segundo $G$. H. se fortalece quando lembramos que a protagonista do romance era uma "escultora": "A mim se referem como a alguém que faz esculturas que não seriam más se tivesse havido menos amadorismo. Para uma mulher essa reputação é socialmente muito, e situou-me, tanto para os outros como para mim mesma, numa zona que fica entre mulher e homem. O que me deixava muito mais livre para ser mulher, já que eu não me ocupava formalmente em sê- lo." (LISPECTOR, 1986, p. 22) 
lembra o longo trajeto da sala de estar à área de serviço, que posteriormente será trabalhado no romance $A$ paixão segundo G.H., onde a personagem - uma bem-sucedida artista plástica moradora de um apartamento no $13^{\circ}$ andar de um prédio - demora-se infinitamente em divagações e digressões até chegar ao quarto da empregada, onde descobre o inseto imundo, esmaga-o num rompante, e depois é levada a provar de sua substância.

Atente-se para o "olhar" das baratas petrificadas pelo efeito das crônicas claricianas: "um tal, tal olhar de censura magoada"(contra quem?). ${ }^{12}$ Atingida por este olhar, e invadida por um sentimento de responsabilidade por compactuar com a lava vulcânica do sistema patriarcal e repressor do qual o jornal, com sua famigerada "coluna feminina", é um dos agentes propagandísticos, a escritora faz um autêntico mea-culpa nesta terceira versão do relato, na qual descreve o processo utilizado para destruir as mulheres "de dentro para fora" ${ }^{13}$

Primeiro vem o açucar: a docilidade e a sedução cor-de-rosa da página, eivada de referências implícitas ao objetivo final, e oculto, desse tipo de literatura: orientar as mulheres sobre as mais diversas formas de agradar os homens, maridos e companheiros, a fim de que eles cumpram o seu papel de lhes dar prazer. Daí a confissão da narradora: "Sei como foi a última noite, sei da orgia no escuro" - que não terá sido, certamente, a orgia da pequena morte literária, pois o texto que se lhes oferece é fraco e vazio; mas uma orgia verdadeira, aquela selvageria que se esconde, inconfessa, sob a intimidade dos corações femininos aparentemente domesticados, e que realmente motiva as mulheres à leitura dessas páginas torpes: a vontade de aprender os segredos da sedução daquele que, esperam elas, lhes dará amor.

\footnotetext{
12 Também neste aspecto vai-se consolidando a hipótese da relação experimental deste conto com o futuro romance $A$ paixão segundo G.H. Em ambos, a personagem se confronta com um olhar exterior de "censura magoada" a ela dirigido. Mas enquanto, no conto, a admoestação refere-se à indiferença da escritora perante o seu público, levando-a a confessar a sua conivência com o sistema repressor que aniquila as mulheres; no romance a questão se adensa. Como sugere Maria de Fátima do Nascimento: "No caso de G. H., trata-se de uma interrupção de gravidez voluntária e com acompanhamento médico. [...] Desde o início da narrativa, ela se condena por isso e, principalmente, por ter decidido em favor da morte. Ela, como mãe, poderia optar pela vida, e não o fez. É disso que, a princípio, ela não consegue se perdoar. [...] Porém, ao término de seu relato, revela-se uma mulher mais amadurecida e segura em relação a suas escolhas existenciais, ao contrário do que se verifica no início da obra". (NASCIMENTO, 2015, pp. 135/148)

${ }^{13}$ Este processo é duramente ressignificado em A paixão segundo G.H. pela opção por uma temática tão conflituosa, abordada de maneira francamente herética: "E estremeci de extremo gozo como se enfim eu estivesse atentando à grandeza de um instinto que era ruim, total e infinitamente doce. Eu me embriagava pela primeira vez de um ódio tão límpido como de uma fonte, eu me embriagava com o desejo, justificado ou não, de matar. ... Ao mesmo tempo eu também havia fechado os olhos. E assim permaneci, toda trêmula. Que fizera eu? Já então talvez soubesse que não me referia ao que eu fizera à barata, mas sim a: que fizera eu de mim?" (LISPECTOR, 1986, p. 49). "Reconhecia na barata o insosso da vez em que eu estivera grávida. ... Durante as intermináveis horas em que andara pelas ruas resolvendo o aborto, que, no entanto, já estava resolvido com o senhor, doutor, durante essas horas meus olhos também deviam estar insossos. ... Mãe, eu só fiz querer matar, mas olha só o que eu quebrei: quebrei um invólucro! De dentro do invólucro está saindo um coração grosso e branco e vivo como pus, mãe, bendita sois entre as baratas, agora e na hora desta tua minha morte.” (LISPECTOR, 1986, pp. 87-90)
} 
A farinha, como um phármakon ${ }^{14}$ - a miscelânea de conteúdos superficiais dessas páginas - é só para fazer fermentar o processo, preencher falsamente o vazio, disfarçar o objetivo orgiástico inconfesso, que oculta o gesso, o veneno. Um veneno que haverá de endurecê-las bem no íntimo de seu ser, algumas "de barriga para cima" mesmo, capturadas na posição que vulnerabiliza as mulheres no ato sexual, e que rouba às baratas e aos insetos cascudos em geral todo o equilíbrio e a possibilidade de andar por suas próprias pernas.

Nesta etapa, Clarice catapulta a história para o âmbito das motivações secretas de seu público, e para uma reflexão sobre o engano das mulheres que tanto se esforçam na busca de um amor que não virá, uma vez que o propósito dos homens com a veiculação e a normatização da imprensa cor-de-rosa, posta à margem do jornal oficial, é dominá-las, imobilizálas e paralisar as suas ações por intermédio de um instrumento de controle social, destruindo suas emoções e pensamentos, sua capacidade de compreensão e de intervenção na realidade. Não há dúvida quanto à decepção das "baratas", as pobres vítimas da ação colonizadora deste contingente populacional pela imprensa:

\begin{abstract}
Outras - subitamente assaltadas pelo próprio âmago, sem nem sequer ter tido a intuição de um molde interno que se petrificava! - essas de súbito se cristalizam, assim como a palavra é cortada da boca: eu te ... Elas que, usando o nome de amor em vão, na noite de verão cantavam. Enquanto aquela ali, a de antena marrom suja de branco, terá adivinhado tarde demais que se mumificara exatamente por não ter sabido usar as coisas com a graça gratuita do em vão: "é que olhei demais para dentro de ..." - de minha fria altura de gente olho a derrocada de um mundo. Amanhece. Uma ou outra antena de barata morta freme seca à brisa. Da história anterior canta o galo. (LISPECTOR, 1987, p.156)
\end{abstract}

O galo já não "canta de galo" na terceira história de Clarice (embora o seu "canto" ainda eco e, de longe, vindo da segunda história), uma vez que se trata, agora, de uma narrativa consciente e conscientizadora do mecanismo perverso capaz de criar nos jornais "sérios" páginas "femininas" específicas, estúpidas e estupidificantes, destinadas a legitimar e a eternizar um estereótipo social da mulher através da lavagem cerebral diária e supostamente inofensiva que impõe às suas vítimas, e cujo objetivo último é manter uma parcela da população, literalmente, alienada, seviciada e "morta” (daí a recorrente alusão à destruição das "antenas" desses seres).

\footnotetext{
${ }^{14} \mathrm{Na}$ obra $A$ farmácia de Platão, Jacques Derrida recupera o mito de Theuth, no qual a escritura é vista como um phármakon, e destaca o duplo sentido do termo, que tanto pode significar remédio quanto veneno: "Ophármakon seria uma substância, com tudo o que esta palavra possa conotar, no que diz respeito a sua matéria, de virtudes ocultas, de profundidade críptica recusando sua ambivalência à análise, preparando, desde então, o espaço da alquimia, caso não devamos seguir mais longe reconhecendo-a como a própria anti-substância: o que resiste a todo filosofema, excedendo-o indefinidamente como não-identidade, não-essência, não-substância, e fornecendo-lhe, por isso mesmo, a inesgotável adversidade de seu fundo e de sua ausência de fundo. Operando por sedução, ophármakon faz sair dos rumos e das leis gerais, naturais ou habituais.” (DERRIDA, 2005, p. 14)
} 
Subversiva até ao extremo na denúncia do que considera um "crime", esta narrativa é tão cuidadosamente elaborada que a subversão passa despercebida, diluída no caráter fluido e intrigante da metafigura. Mas a narradora, agora, também já não se define como uma "barata esperta": é indubitavelmente "gente", e contempla novamente, de sua "fria altura", a devastação que ajudou a provocar no seu público vulgar e desqualificado.

Mas a sua redenção virá de um investimento numa "quarta história", que assim se anuncia, como uma anunciação de seu novo e recém-encontrado estilo na prática diária com a atividade infamante. Atividade esta que lhe terá possibilitado tanto a experiência de uma epifania pessoal e existencial sobre a sua missão no mundo, como uma epifania profissional, sobre a guinada a dar na sua forma de escrever, que não poderia prescindir de atingir também, ainda que missionariamente, o público feminino e "barato" das crônicas. Terá sido, talvez, neste momento, que Clarice ter-se-á dado conta do poder da epifania inclusivamente como estratégia literária, que lhe permitirá partir do "açúcar e da farinha" dos temas femininos vulgarizados na imprensa para seduzir um público maior, antes considerado "inferior", a fim de familiarizá-lo com suas reflexões sublimes e elevadas, críticas e herméticas, eliminando o "gesso" venenoso da receita (mas quem sabe substituindo-o por outro ingrediente ainda mais perigoso?) . E será exatamente isto o que ela fará no seu livro divisor de águas, a coletânea de contos Laços de família. A decisão é explicitada na história que se segue:

\begin{abstract}
A quarta narrativa inaugura nova era no lar. Começa como se sabe: queixei-me de baratas. Vai até o momento em que vejo os monumentos de gesso. Mortas, sim. Mas olho para os canos, por onde esta mesma noite renovar-se-á uma população lenta e viva em fila-indiana. Eu iria então renovar todas as noites o açúcar letal? como quem já não dorme sem a avidez de um rito. E todas as madrugadas me conduziria sonâmbula até o pavilhão? no vício de ir ao encontro das estátuas que minha noite suada erguia. Estremeci de mau praqer à visão daquela vida dupla de feiticeira. E estremeci também ao aviso do gesso que seca: o vício de viver que rebentaria meu molde interno. Áspero instante de escolha entre dois caminhos que, pensava eu, se dizem adeus, e certa de que qualquer escolha seria a do sacrifício: eu ou minha alma. Escolhi. E hoje ostento secretamente no coração uma placa de virtude: "Esta casa foi dedetizada”. (LISPECTOR, 1987, p.157)
\end{abstract}

Incapaz de retroceder na destruição já provocada com a sua intervenção conivente com o sistema, Clarice admite que ainda há esperança para as novas gerações: toda a "população lenta e viva em fila-indiana" que continuará subindo pelos canos para a sua "área de serviço", invadindo faminta a sua casa em busca de conhecimento. E interroga-se sobre o que desejará fazer com este público: se assumirá o vício fácil e profissionalmente sedutor das iscas de açúcar, talvez mais rendoso em termos financeiros e com maiores perspectivas de retorno do que o exercício solitário da literatura estética e eticamente comprometida. Ou se manterá uma vida dupla: voltada num primeiro momento para uma prática de sobrevivência, na qual continuará “assassinando” mulheres, e da qual poderá retornar num outro momento, 
voltado à satisfação de seus prazeres intelectuais, quando será possível esquecer esse cotidiano envenenamento dos imundos, dirigindo-se apenas aos vivos e eleitos.

Uma tal perspectiva lhe parece imediatamente delirante: ela vibra de prazer ante essa opção, mas sabe que é um "mau” prazer. Um prazer que a conduzirá, como à barata da história anterior (aquela que não soube "usar as coisas com a graça gratuita do em vão" e que decidiu "olhar demais para dentro de si mesma"), a um ensimesmamento mórbido, a um engessamento que acabará por fazer rebentar, também, o seu próprio molde de escritora. Embora não revele a escolha que, feiticeira, terá realizado entre os seus interesses e o seu senso ético, o fato de concluir com a revelação da casa enfim "dedetizada"; fechada, portanto, à luxúria do crime diário e aos arroubos da contemplação, a cada manhã, dos cadáveres petrificados pela sua palavra envenenada, supõe-se que Clarice terá optado (como deveras o fez), pela sua alma: o exercício exclusivo da escrita literária.

Uma opção atingida não sem conflito, mas perpassada pela revolta demasiadamente humana contra o que considera, talvez, um excessivo escrúpulo moralista, que resultará num ônus à sua vida prática, o que explica a alusão irônica à "placa de virtude" que passou a “ostentar secretamente no coração". Este ponto da história é quase um lamento, como a dúvida que acomete o Cristo na cruz, quando clama aos céus: “Eli, Eli, lama sabachtani”. Mas que não a impediu, apesar da assumida imolação - ironicamente associada ao caráter sacrificial da missão redentora de um filósofo racionalista em meio a povos primitivos - de seguir adiante com o seu transcendental propósito, o de tornar-se a escritora que hoje é, e que amanhã virá a ser, e que ainda o será depois de amanhã, e depois. E que por isso, sabiamente, já anunciava com inegável bom-humor - no enigmático título de sua "quinta história” ainda não narrada, que termina exatamente onde começa - a certeza de um futuro para a sua carreira, proclamado apoteoticamente como quem anuncia um Quinto Império por vir, mas que já é:

A quinta história chama-se "Leibniz e a Transcendência do Amor na Polinésia". Começa assim: queixei-me de baratas. (LISPECTOR, 1987, p.157)

\section{CLARICE LISPECTOR'S METAMORPHOSIS}

ABSTRACT: Clarice Lispector's work takes a turn from the 1960s, with the book of short stories Family ties, written during her professional experience as a journalist responsible for the female columns published in the Rio press in this decade. The obsessive mention of the recipe "How to kill cockroaches" in these pages, which gives rise to the short story "The fifth story", and later to the novel Thepassion according to GH, reveals that the author will have glimpsed in the figure of this insect a specular potential capable of trigger a metalinguistic reflection on the process of metamorphosis of her style after her practice as a chronicler.

KEYWORDS: "The fifth story”; Cockroach; Clarice Lispector; Metafigure. 


\section{REFERÊNCIAS}

BARTHES, Roland. O prazer do texto. São Paulo: Perspectiva, 1987.

DERRIDA, Jacques. A farmácia de Platão. São Paulo: Iluminuras, 2005.

FREUD, Sigmund. O mal-estar na civilização. São Paulo: Penguin Classics Companhia das Letras, 2011.

GOTLIB, Nádia Batella. Clarice: uma vida que se conta. São Paulo: Edusp, 2009.

KAFKA, Franz. A metamorfose. São Paulo: Companhia das Letras, 2000.

LISPECTOR, Clarice. Correio feminino. Organização de Aparecida Maria Nunes. Rio de Janeiro: Rocco, 2006. 2008.

Sópara mulheres. Organização de Aparecida Maria Nunes. Rio de Janeiro: Rocco,

_. Laços de família. Rio de Janeiro: Nova Fronteira, 1983.

. A paixão segundo G. H. Rio de Janeiro: Nova Fronteira, 1986. 1987. A quinta história, in: Felicidade clandestina: contos. Rio de Janeiro: Nova Fronteira,

LYOTARD, Jean-François. O inumano. Considerações sobre o tempo. Lisboa: Editorial Estampa, 1997.

MITCHELL, W.J.T. Picture theory: essays on verbal and visual representation. Chicago and London: The University of Chicago Press, 1994.

NASCIMENTO, Maria de Fátima. Releitura do romance A paixão segundo G. $H$., de Clarice Lispector: o aborto voluntário de G. H. simbolizado na morte de uma barata, in: Revista Brasileira de Literatura Comparada (vol. 17, n. 27, 2015, pp. 131-150).

NOLASCO, Edgar Cézar. Clarice Lispector: nas entrelinhas da escritura. São Paulo: Annablume, 2001.

NUNES, Aparecida Maria. Clarice Lispector jornalista: páginas femininas \& outras páginas. São Paulo: Editora Senac São Paulo, 2006.

NUNES, Benedito. O drama da linguagem: uma leitura de Clarice Lispector. São Paulo: Ática, 1989.

RONCADOR, Sônia. Poéticas do empobrecimento: a escrita derradeira de Clarice Lispector. São Paulo: Annablume, 2002.

SARTRE, Jean Paul. A náusea. Lisboa: Publicações Europa-América, s/d.

Recebido em: 03/08/2020.

Aprovado em: 16/11/2020. 